\title{
SHIITAKE LENTINULA EDODES PRODUCTION ON A STERILIZED BAGASSE SUBSTRATE ENRICHED WITH RICE BRAN AND SUGARCANE MOLASSES
}

\author{
Ivan Henrique Rossi ${ }^{1}$; Antonio Carlos Monteiro ${ }^{1 *}$; José Octavio Machado ${ }^{1}$; João Luciano Andrioli ${ }^{1}$; \\ José Carlos Barbosa ${ }^{2}$
}

${ }^{1}$ Laboratório de Microbiologia, Departamento de Produção Vegetal e ${ }^{2}$ Departamento de Ciências Exatas, Faculdade de Ciências Agrárias e Veterinárias, Universidade Estadual Paulista, Jaboticabal, São Paulo, SP, Brasil.

Submitted: January 20, 2002; Approved: December 16, 2002

\begin{abstract}
This investigation was performed to evaluate the biological efficiency (BE), mean mushroom weight (MMW), mean number of mushroom (MNM) and mushroom quality of Shiitake [Lentinula edodes (Berk.) Pegler] when grown on a sterilized substrate composed by sugarcane bagasse enriched with rice bran and sugarcane molasses. The proportions of rice bran were $0,15,20,25$ and $30 \%$ (dry weight/dry weight of bagasse); and the concentrations of sugarcane molasses were 0,30 and $60 \mathrm{~g} / \mathrm{kg}$ (dry weight/dry weight of bagasse plus rice bran). Four flushes were obtained during the production cycle, providing 3 accumulated productions which were used for production analysis. The substrate supplemented with 25 and 30\% rice bran yielded the highest BE (98.42 and 99.84\%, respectively, about 230 days after spawning) and MNM and initially produced a lower MMW than the substrates supplemented with 15 and $20 \%$ rice bran. Any amount of rice bran added to the sugarcane bagasse improved mushroom quality, with the best production of marketable mushrooms obtained by the addition of $15 \%$ rice bran. The largest amount of sugarcane molasses $(60 \mathrm{~g} / \mathrm{kg})$ increased BE $(90.3$ and $23.6 \%$, on first and second accumulated productions, respectively) and MNM and no quantity affected mushroom quality.
\end{abstract}

Key words: Lentinula edodes, shiitake, sugarcane bagasse

\section{INTRODUCTION}

Over the last few years, the commercial cultivation of Shiitake, Lentinula edodes, on artificial substrates based on enriched sawdust has increased $(5,15)$. The productivity of this system depends, among other factors, on the quality of the sawdust used as substrate (23). Sawdust is difficult to standardize because it is generally obtained from residues of different types of wood. Thus, the availability of low-cost and homogeneous substrates for production is an important factor for successful cultivation (26). Since edible mushrooms are adapted to grow on a variety of ligno-cellulosic wastes (2), it is possible to use a wide variety of unconventional materials to cultivate $L$. edodes.
According to Santos (22), bagasse is the residue of sugarcane submitted to several types of treatments and washes performed during sugar extraction. Sugarcane bagasse, besides being a highly available waste product in sugar and alcoholproducing areas, is rich in lignin, cellulose and hemicellulose (3). Moreover, bagasse is a homogeneous raw material in terms of chemical composition and physical and bromatologic characteristics (16), important factors for the cultivation of $L$. edodes. In addition, when pressed, sugarcane bagasse is porous enough to support the mycelial growth of $L$. edodes and also to facilitate the gas exchanges of the substrate. Nevertheless, basidiocarp production can be reduced in this material due to the shortage of nutrients, as observed by Maziero (14) and Soto-

\footnotetext{
* Corresponding author. Mailing address: Laboratório de Microbiologia, Departamento de Produção Vegetal, Faculdade de Ciências Agrárias e Veterinárias, UNESP, Via de Acesso Prof. Paulo Donato Castellane, s/n, 14884-900, Jaboticabal, SP, Brasil. Telephone: (+5516) 3209-2652/32092653. Fax: (+5516) 3203-4275. E-mail: montecar@,fcav.unesp.br
} 
Velazco et al. (24) for Pleurotus sp culture. Thus, supplementation with nutrients is desirable. Sugarcane molasses is a subproduct rich in sugars, abundantly found in areas of high bagasse availability. Sugars can increase mushroom yield $(20,25)$, because it is a source of energy for the metabolic activity of the mushrooms, supplying carbon, which represents almost $50 \%$ of the dry matter weight of fruiting bodies (27). Rice bran, a readily available residue in areas of rice processing, is traditionally employed to enrich the sawdust used, in the orient, for production of $L$. edodes mushrooms $(10,12,13)$ and can be used to supplement sugarcane bagasse, as suggested by Oei (17) and by Eira and Minhomi (7), and as used by Iizuka (11) for the production of $L$. edodes mycelial extracts. The objective of the present study was to evaluate the production and quality of L. edodes mushrooms in axenic culture grown on sugarcane bagasse supplemented with different amounts of rice bran and sugarcane molasses.

\section{MATERIALS AND METHODS}

A culture of the JAB-K1 isolate grown on minimum medium (18) from basidiocarp of L. edodes (Berk.) Pegler, obtained from growers of the northeast region of São Paulo State, Brazil, was used as an inoculum for the production of the initial spawn obtained by cultivation of the fungus on a sugarcane bagasse substrate supplemented with $20 \%$ rice bran and $30 \mathrm{~g}$ of sugarcane molasses per kg of substrate. This initial spawn was then propagated in a substrate with the same composition to produce the spawn used in the experiment.

The sugarcane bagasse was supplemented with nondefatted rice bran, sugarcane molasses and mixtures of the two supplements, representing the variables of the experiment. The amount of water needed to correct the moisture content of the substrate to $60 \%$ (21) was calculated considering the amount of natural humidity of each component. Rice bran was mixed with bagasse before the increase in moisture content and the molasses was diluted in the water used to correct moisture. The substrate, pressed manually into a cylindrical block, was packed in two high density polyethylene bags resistant to autoclaving (13). Each experimental replicate consisted of a cylindrical block of substrate weighing $1.2 \mathrm{~kg}$ and measuring $15.0 \mathrm{~cm}$ in diameter and 15.0 to $20.0 \mathrm{~cm}$ in height, with a central cylindrical hole 3.0 $\mathrm{cm}$ in diameter running throughout the block to provide space for inoculation with approximately $4.7 \%$ of spawn (1).

The blocks were sterilized for 120 minutes at $121^{\circ} \mathrm{C}$ immediately after preparation and stored until the time for inoculation. The experimental treatments consisted of a $5 \times 3$ factorial scheme with 5 proportions of rice bran $(0,15,20,25$ and $30 \%$, dry weight/dry weight of bagasse) and 3 concentrations of sugarcane molasses $(0,30$ and $60 \mathrm{~g} / \mathrm{kg}$, dry weight $/$ dry weight of bagasse plus rice bran). The experiment was arranged as a completely randomized design with different numbers of replicates (a minimum of 5 and a maximum of 10 blocks per treatment), because any substrate presenting the slightest suspicion of contamination was immediately eliminated.

After spawning, the substrates were incubated at $25-28^{\circ} \mathrm{C}$ in the dark in the presence of $70 \%$ humidity $(1,26)$ until they were ready for fruiting, as indicated by complete colonization of the substrate and mycelial thickening $(6,17)$. After 60 days $(11,13)$, the bags were removed to expose the surface of the blocks to fluorescent light ( $12 \mathrm{~h} / \mathrm{d})$ for 15 days. After bag removal, a hard and thick brown coat formed on the surface of the block. During this phase, environmental humidity was raised to $90-95 \%$ in order to prevent water loss from the blocks. The blocks were then soaked in cold water (a minimum of 16 and a maximum of $26^{\circ} \mathrm{C}$ ) in a tank for 24 hours (19) and then placed in a fruiting room with a controlled temperature of 21 to $23^{\circ} \mathrm{C}$ and relative humidity between 90 and $95 \%$. The mushrooms were harvested over a period of 12 days starting 8 days after induction. Four flushes were obtained. Yield and quality were evaluated considering the accumulated productions of the flushes, i.e., the sum of the first two flushes represented the first accumulated production and so forth.

For the evaluation of productivity, the following parameters were used: biological efficiency (BE), calculated as the mushroom fresh weight/block dry weight ratio x 100 (21); mean number of mushrooms (MNM), corresponding to number of basidiocarps per block, and mean mushroom weight (MMW). The quality of the basidiocarps was evaluated on the basis of four size groups (larger than $7 \mathrm{~cm}, 5$ to $7 \mathrm{~cm}, 3$ to $5 \mathrm{~cm}$, and smaller than $3 \mathrm{~cm}$ ), and a "deformed" group. Marketable mushrooms are those measuring more than $3 \mathrm{~cm}$ in size, and mushrooms of highest commercial value are those measuring more than $5 \mathrm{~cm}$ in diameter.

After harvesting, the blocks were kept at 25 to $28^{\circ} \mathrm{C}$ and 85 to $90 \%$ relative humidity during 30 days for the resting period and later fruiting induction (13). The procedure was repeated until full substrate consumption. The harvest period was of about 230 days.

\section{RESULTS}

In the first harvest, a small number of mushrooms was obtained in all treatments, a fact that prevented statistical analysis of the data. However, these results were included in the analysis of accumulated productions. In the second flush, only treatments with $0 \%$ rice bran did not produce sufficient numbers of mushrooms, however these data were also included in the analysis of accumulated production.

\section{Substrate Productivity}

Any amount of rice bran added to the sugarcane bagasse increased $\mathrm{BE}$ and $\mathrm{MNM}$ (Table 1). The largest rice bran proportions (25 and 30\%) stimulated mushroom yields in the 
first flushes but in the subsequent stimulation was lower (15 and $20 \%$ ), indicating, in this phase, the exhaustion of the substrate with largest amounts of rice bran.

The addition of 25 and $30 \%$ of rice bran led to lower MMW in the initial accumulated production (Table 1). In the subsequent accumulated productions no effect of rice bran on MMW was verified. Analysing BE, MNM and MMW jointly, the addition of 25 and $30 \%$ rice bran stimulated mushroom yield in the first two accumulated productions even though it had reduced the mean weight in the initial accumulated production (Table 1).

Any amount of molasses increased the biological efficiency and mean number of $L$. edodes mushrooms in the first accumulated production but in the second only an increase on $\mathrm{BE}$ by the addition of $60 \mathrm{~g}$ of molasses was observed (Table 1). The effect of the supplementation on MMW was only observed in the last accumulated production by the addition of $60 \mathrm{~g}$ of molasses to the substrate. MMW decreased in each accumulated production, demonstrating the exhaustion of the substrate.

\section{Mushroom Quality}

Supplementation of bagasse with $15 \%$ rice bran stimulated the production of mushrooms exceeding $7 \mathrm{~cm}$ in diameter, and 25 to $30 \%$ rice bran addition increased mushroom production in the 5 to $7 \mathrm{~cm}$ size group (Fig. 1A). Rice bran had no effect on the size group exceeding $7 \mathrm{~cm}$ or on the group of deformed mushrooms, but stimulated production in the size groups of 5 to 7 and 3 to $5 \mathrm{~cm}$ (Fig. 1B). The addition of 20 to $25 \%$ rice bran stimulated the production of mushrooms exceeding $7 \mathrm{~cm}$ in diameter (Fig. 1C).
In the no rice bran added treatment, the sum of the percentages of no commercial groups (deformed or less than 3 $\mathrm{cm}$ in diameter) reached to $40 \%$ of the harvested mushrooms, depending on the accumulated production considered. Any amount of added rice bran reduced this percentage greatly from 12 to $25 \%$. Thus, the addition of $15 \%$ of rice bran to the sugarcane bagasse substrate stimulated the production of mushrooms of better quality.

The effect of the sugarcane molasses was observed on the 5 to $7 \mathrm{~cm}$ size and deformed groups in the initial accumulated production (Fig. 2A). The concentration of $60 \mathrm{~g} / \mathrm{kg}$ yielded a larger number of mushrooms in the former group and a smaller number in the latter. Among the other accumulated productions (Figs. 2B and C), only in the last it was observed effect of the 60 $\mathrm{g} / \mathrm{kg}$ concentration on the group of mushrooms exceeding $7 \mathrm{~cm}$ in diameter. These results demonstrate that molasses, when used as a supplement in the substrate based on sugarcane bagasse, had no significant effect on the quality of $L$. edodes mushrooms.

\section{DISCUSSION}

The low productivity obtained in the first flush may be explained by the incubation period and the use of two plastic bags for the protection of the substrate during colonization by L. edodes. All the substrates were totally colonized by 60 days after inoculation and received the first soaking at 75 days. A time period of 60 to 90 days is necessary for incubation $(11,13)$ but our results suggest that early fruiting was induced before maturation of the mycelium. The gas exchanges between the substrates and the environment might have been impaired by

Table 1. Effect of the amounts of rice bran and sugarcane molasses on the biological efficiency (BE), mean number of mushrooms $(\mathrm{MNM})$ and mean mushroom weight (MMW) of Lentinula edodes, observed in three accumulated productions ${ }^{\text {. }}$.

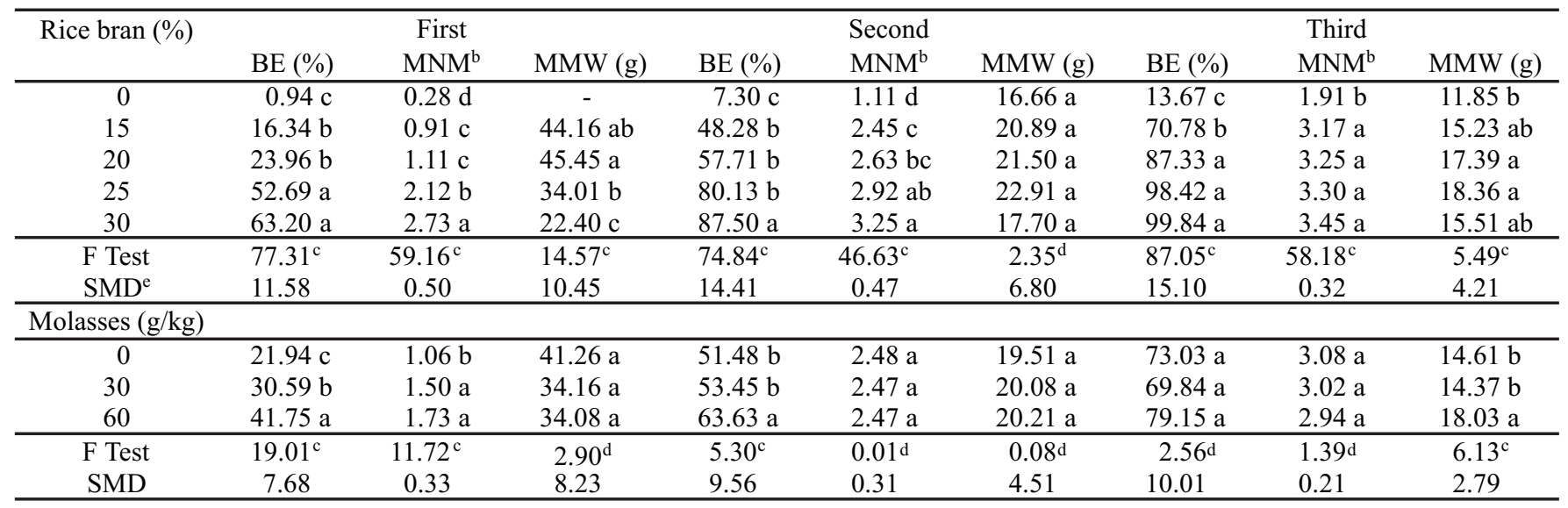

${ }^{a}$ Means followed by same letter in a column did not differ by the Tukey test at the $5 \%$ level of probability; ${ }^{b}$ Data transformed to $\log \mathrm{x}+1 ;{ }^{\mathrm{c}}$ Significant at the $1 \%$ level of probability by the Tukey test; ${ }^{\mathrm{d}}$ Not significant; ${ }^{\mathrm{e}} \mathrm{SMD}=$ Significant minimum difference. 

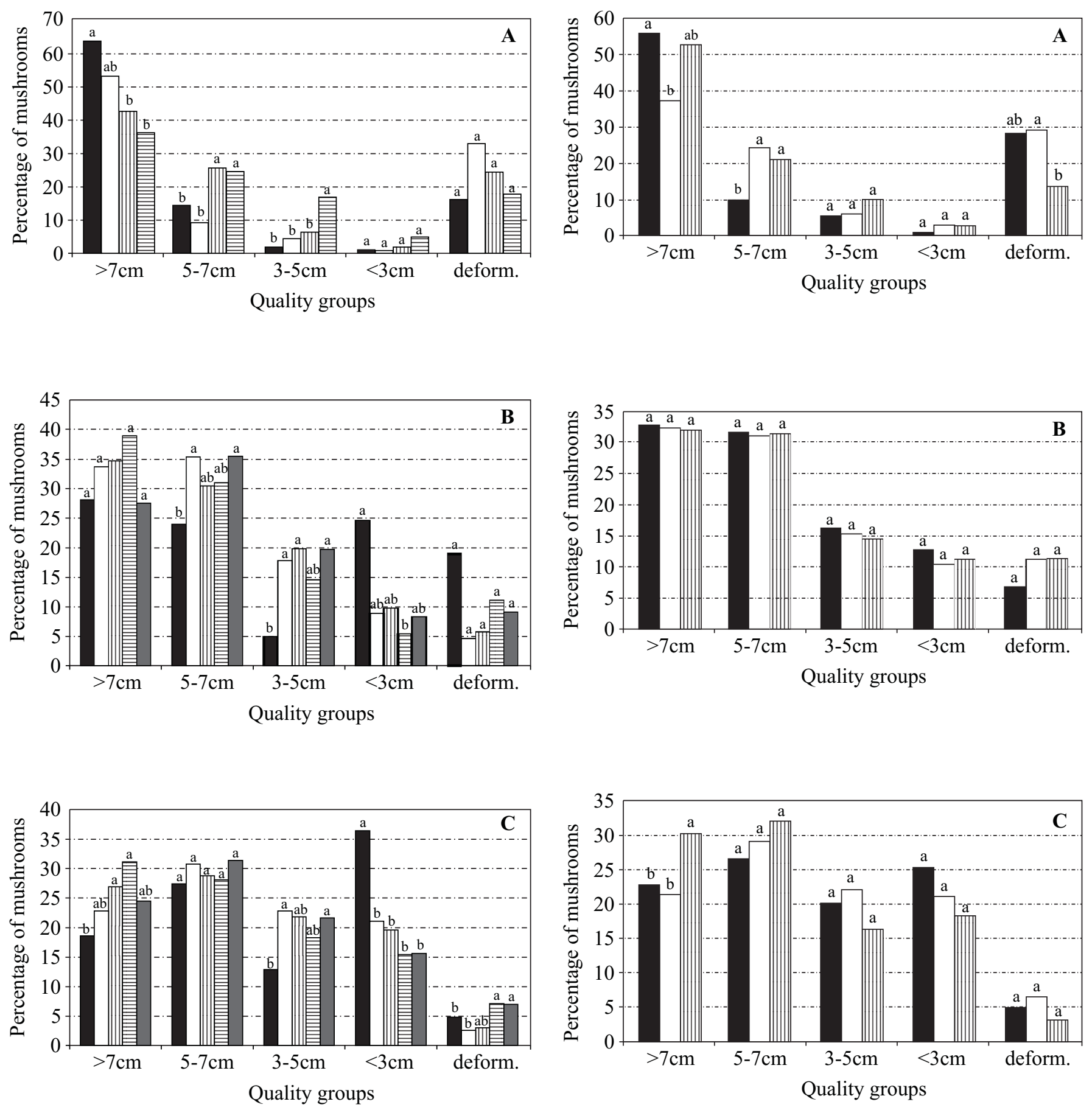

$0 \%$ rice bran $\square 15 \% \quad$ 盂 $20 \% \quad$ 具 $25 \% \quad \square 30 \%$

Figures 1A, B and C. Effect of the proportions of rice bran on the quality of $L$. edodes mushrooms evaluated by size group and deformation group. A. First accumulated production. B. Second accumulated production. C. Third accumulated production. Means were compared within each quality group by Tukey's test.

$0 \mathrm{~g}$ of molasses $/ \mathrm{kg}$ of sustrate $\square 30 \mathrm{~g} / \mathrm{kg} \quad$ 血 $60 \mathrm{~g} / \mathrm{kg}$

Figures 2A, B and C. Effect of the concentrations of sugarcane molasses on the quality of $L$. edodes mushrooms evaluated by size group and deformation group. A. First accumulated production. B. Second accumulated production. C. Third accumulated production. Means were compared within each quality group by Tukey's test. 
the use of two bags, so that the accumulation of $\mathrm{CO}_{2}$ during the growth of $L$. edodes might have increased the time needed for incubation. Several authors have pointed out the impairment of L. edodes development caused by inadequate gas exchange of the substrates $(5,6)$. Kawai et al. (13) obtained good production with substrates placed in plastic bags with greater permeability for exchange, but Donoghue and Denison (5) observed no difference in productivity with substrates placed in plastic bags with different openings for gas exchange. On this basis, we expected the use of two plastic bags, necessary to maintain the aseptic conditions of the substrate, not to impair mushroom yield. Thus, further studies are needed to determine the time economically viable for inducing the initial production and the best methods for substrate packing for the growth and production of $L$. edodes on sugarcane bagasse.

The low production obtained on bagasse without rice bran clearly shows the need for supplementation in order to increase the production of $L$. edodes mushrooms. The higher productivity was obtained by the addition of 25 and 30\% rice bran. Eira and Minhomi (7) reported that $L$. edodes can be cultivated axenically on bagasse supplemented with $20 \%$ rice bran and other nutrients. According to Fasidi and Kadiri (8), the increased productivity of Lentinus subnudus on a Andropogun tectorum straw substrate supplemented with $30 \%$ rice bran can be attributed to the carbohydrates, amino acids and mineral elements present in this supplement. These authors also believe that the lipids present in rice bran provide a higher mushroom yield, in agreement with Song et al. (23) who observed a gradual decrease in lipids in the substrate after the production of mushrooms. Several authors $(1,4,10)$ have reported increase in BE quite similar to that obtained in the present study. The increase in BE obtained with increasing rice bran proportions was not linear, i.e., the increase in $\mathrm{BE}$ with each $5 \%$ increment in the amount of rice bran added was not proportional. The growth tendency was similar to that detected by Royse (21), who observed a $13.5 \%$ increase in BE over three flushes with each $6 \%$ amount of millet added to sawdust. In the present study, the mean increase obtained for three accumulated productions was approximately $12 \%$.

The rice bran proportions that led to an increase in MNM and BE also caused a decrease in MMW. Similar effect was observed by Royse (21). According to Royse et al. (20) and Donoghue and Denison (6), larger and heavier mushrooms are obtained when lower BE is observed. In the present experiment, this relationship was observed only for the initial accumulated production, whereas in the second flush MMW did not differ when the four proportions of supplementation with rice bran were considered. Both MNM and BE were higher when the 25 and $30 \%$ supplements were used, suggesting that these amounts of bran stimulates the production of good quality mushrooms of good mean weight.

The addition of any amount of rice bran to sugarcane bagasse showed an improvement in mushroom quality, with the production of marketable mushrooms ranging from 75 to $88 \%$. These results were superior to the 60 to $80 \%$ yields reported to occur by Hiromoto (9) when L. edodes is cultivated on supplemented sawdust.

The increment in productivity with addition of molasses suggests that this supplement also can be added to sugarcane bagasse for the cultivation of $L$. edodes. Tokimoto and Kawai (25) showed that the enlargement of the proportion of sucrose from 0.5 to $8.0 \%$ in potato-agar medium stimulated the production of $L$. edodes. Since $60 \mathrm{~g} / \mathrm{kg}$ of substrate practically represent $5.0 \%$ sucrose, our results correspond to those obtained by these authors. Royse et al. (20) obtained a $22 \%$ increase in $\mathrm{BE}$ in the first flush by the addition of 0.6 to $1.2 \%$ sucrose. When they doubled the amount of sugar $(2.4 \%)$ they did not observe a further increase in production. The stimulation of production observed by these authors occurred in the first induction, whereas in the present study it occurred in the second. Nevertheless, the data obtained in the two studies were similar after the second induction, since we obtained a $10 \%$ increase in BE when we added $30 \mathrm{~g} / \mathrm{kg}$ molasses and a $20 \%$ increase when we added $60 \mathrm{~g} / \mathrm{kg}$ molasses. This increase is explained by the fact that molasses is a source of energy and of carbon which, according to Zanetti and Ranal (27), are important for the metabolic activity of the mushrooms and represent the basis for the synthesis of various molecules that result in about $50 \%$ dry weight of fruiting bodies as carbon. We found no effect of molasses on the quality of mushrooms produced on sugarcane bagasse, similarly to observed by Royse et al. (20).

\section{ACKNOWLEDGMENTS}

We thank FAPESP (Fundação de Amparo à Pesquisa do Estado de São Paulo, Brazil) for M. Sc. scholarship.

\section{RESUMO}

\section{Produção de shiitake (Lentinula edodes) em substrato esterilizado, elaborado à base de bagaço de cana-de-açúcar, suplementado com farelo de arroz e melaço de cana-de-açúcar}

Este trabalho foi conduzido com o objetivo de avaliar a eficiência biológica (EB), o peso e número médio (PMC e NMC) e a qualidade dos cogumelos de Shiitake [Lentinula edodes (Berk.) Peger] cultivado em substrato esterilizado, elaborado à base de bagaço de cana-de-açúcar, enriquecido com farelo de arroz e melaço de cana-de-açúcar. As proporções de farelo de arroz usadas foram $0,15,20,25$ e 30\% (peso seco/peso seco de bagaço) e as concentrações de melaço de cana-de-açúcar utilizadas foram 0,30 e $60 \mathrm{~g} / \mathrm{kg}$ (peso seco/peso seco de bagaço mais farelo de arroz). Obteve-se quatro colheitas, constituindo três produções acumuladas que foram usadas para as análises 
de produção. Os substratos contendo 25 e $30 \%$ de farelo de arroz produziram os maiores valores de EB (98,42 e 99,4\%, respectivamente, cerca de 230 dias após a inoculação) e PMC, e inicialmente, produziram um NMC menor que os substratos contendo 15 e $20 \%$ de farelo de arroz. Qualquer quantidade de farelo de arroz adicionado ao bagaço de cana-de-açúcar melhorou a qualidade dos cogumelos e a melhor produção de cogumelos comercializáveis foi obtida com a adição de $15 \%$ de farelo de arroz. A maior quantidade de melaço de cana-de-açúcar $(60 \mathrm{~g} / \mathrm{kg})$ aumentou a EB $(90,3$ e 23,6\%, na primeira e segunda produções acumuladas, respectivamente) e PMC, e nenhuma quantidade adicionada influenciou a qualidade dos cogumelos.

Palavras-chave: Lentinula edodes, Shiitake, bagaço de canade-açúcar.

\section{REFERENCES}

1. Bis'ko, N.A.; Bilay, V.T. Some physiological aspects of the cultivation of Lentinula edodes (Berk.) Singer. In: Royse, D. (ed). Proceedings of the $2^{\text {nd }}$ International Conference on the Mushroom Biology and Mushroom Products. Penn. State University, University Park, Pennsylvania, 1996, p. 381-386.

2. Buswell, J.A.; Cai, Y.J.; Chang, S.T. Ligninolytic enzyme production and secretion in edible mushroom fungi. In: Royse, D. (ed). Proceedings of the $2^{\text {nd }}$ International Conference on the Mushroom Biology and Mushroom Products. Penn. State University, University Park, Pennsylvania, 1996, p. 113-122.

3. Burgi, R. Produção de cana-de-açúcar auto-hidrolisada e avaliação do seu teor nutritivo para ruminantes. Piracicaba, 1985, 110p. (M.Sc. Dissertation, Escola Superior de Agricultura "Luiz de Queiroz", USP).

4. Diehle, D.A.; Royse, D.J. Shiitake cultivation on sawdust: evaluation of selected genotypes for biological efficiency and mushroom size. Mycologia, 78: 929-933, 1986.

5. Donoghue, J.D.; Denison, W.C. Shiitake cultivation: gas phase during incubation influences productivity. Mycologia, 87: 239-244, 1995.

6. Donoghue, J.D.; Denison, W.C. Commercial production of shiitake (Lentinula edodes) using whole-log chip of Quercus, Lithocarpus, and Acer. In: Royse. D. (ed.). Proceedings of the $2^{\text {nd }}$ International Conference on the Mushroom Biology and Mushroom Products. Penn. State University, University Park, Pennsylvania, 1996, p. 265-275.

7. Eira, A.F.; Minhomi, M.T.A. Manual teórico-prático do cultivo de cogumelos comestiveis. FEPAF, Botucatu, 1996, 96p.

8. Fasidi, I.O.; Kadiri, M. 1993 Use of agricultural wastes for the cultivation of Lentinus subnudus (Polyporales: Polyporaceae) in Nigeria. Rev. Biol. Trop., 41: 411-415, 1993.

9. Hiromoto, B.T. Comparative analysis of shiitake culture systems. In: Mahler, M. (ed.). Proceedings of the $13^{\text {th }}$ Mushroom Science. Science and Cultivation of Edible Fungi, vol 2. Balkema, Rotterdam, 1991, p. 489-496.
10. Ho, M.S. A new technology "plastic bag cultivation method" for growing shiitake mushroom. In: Grabbe, K.; Hilber, O. (eds.). Proceedings of the $12^{\text {th }}$ International Congress on the Science and Cultivation of Edible Fungi, part 2. Braunschweig, Germany, 1989, p. 303-307.

11. Iizuka, H. Production of Lentinus edodes mycelia extracts (LEM). Food Rev. Intern., 13: 343-348, 1997.

12. Ikegaya, N. Breeding. Food Rev. Intern., 13: 335-343, 1997.

13. Kawai, G.; Kobayashi, H.; Fukushima, Y.; Yamada, S.; Fuse, H.K.; Ohsaki, K. Continuous manufacturing system of solid culture media packed in film bags for cultivation of shiitake. Food Rev. Intern., 13: 349-356, 1997.

14. Maziero, R. Substratos alternativos para o cultivo de Pleurotus spp. São Paulo, 1990, 136p. (M.Sc. Dissertation, Instituto de Biociências, USP).

15. Miles, P.G.; Chang S.T. Mushroom biology: concises basics and current developments. World Scientific, Singapore, 1997, 194p.

16. Nussio, L.G.; Balsalobre, M.A.A. Utilização de resíduos fibrosos da industrialização da cana-de-açúcar na alimentação de bovinos. IV Simpósio sobre Nutrição de Bovinos, Piracicaba, 1993, p. 127-150.

17. Oei, P. Manual on mushroom cultivation. Techniques, species and opportunities for commercial application in developing countries. TOOL Foundation, Amsterdam, 1991, 249p.

18. Pontecorvo, G.; Roper, J.A.; Hemmons, L.M.; McDonald, K.D.; Bufton, A.W.J. The genetics of Aspergillus nidulans. Adv. Genet., 5: 141-238, 1953.

19. Przybylowicz, P.; Donoghue, J. Shiitake growers handbook: the art and science of mushroom cultivation. Kendall/Hunt, Iowa, 1988, $217 \mathrm{p}$.

20. Royse, D.J.; Bahler, B.D.; Bahler, C.C. Enhanced yield of Shiitake by saccharide amendment of the synthetic substrate. Appl. Environ. Microbiol., 52: 479-482, 1990.

21. Royse, D.J. Yield stimulation of shiitake by millet supplementation of wood chip substrate. In: Royse, D. (ed.). Proceedings of the $2^{\text {nd }}$ International Conference on the Mushroom Biology and Mushroom Products. Penn. State University, University Park, Pennsylvania, 1996, p. 277-283.

22. Santos, F.A.P. O bagaço de cana-de-açúcar tratado sob pressão de vapor como alternativa para a alimentação de bovinos na entressafra das pastagens. Sociedade Brasileira de Zootecnia, Campinas, 1990, 203 p.

23. Song, C.H.; Cho, K.Y.; Nair, N.G.; Vine, J. Growth stimulation and lipid synthesis in Lentinus edodes. Mycologia, 81: 514-522, 1989.

24. Soto-Velazco, C.; Guzmán-Dávalos, L.; Télles, C. Substrates for cultivation of Pleurotus in Mexico: II. sugarcane bagasse and corn stover. Mushr. J. Tropics, 11: 34-37, 1991.

25. Tokimoto, K.; Kawai, A. Nutritional aspects on fruit-body development in replacement culture of Lentinus edodes (Berk.) Sing. Rept. Tottori Mycol. Inst. (Japan), 12: 25-30, 1975.

26. Worral, J.J.; Yang, C.S. Shiitake and oyster mushroom production on apple pomance and sawdust. Hort. Sci., 27: 1131-1133, 1992.

27. Zanetti, A.; Ranal, M.A.; Suplementação da cana-de-açúcar com guandu no cultivo de Pleurotus sp. 'Florida'. Pesq. Agrop. Bras., 32: 959-964, 1997. 